\title{
Policy on Enhancing Access to Higher Education: The Israeli Case
}

\author{
Pinhas Haliwa ${ }^{1}$ \\ ${ }^{1}$ CEO, Ashkelon Academic College, Ashkelon, Israel \\ Correspondence: Pinhas Haliwa, CEO, Associate Professor, Department of Criminology, Government, and Politics, \\ Ashkelon Academic College, Ashkelon, Israel. E-mail: Pinhash@aac.ac.il \\ Received: December 20, 2021 \\ Accepted: January 15, 2022 \\ Online Published: January 20, 2022 \\ doi:10.5430/irhe.v6n4p40 \\ URL: https://doi.org/10.5430/irhe.v6n4p40
}

\begin{abstract}
Israel's new higher education policy, introduced by the Council for Higher Education (CHE) in 1994, was intended to make higher education accessible to population groups on the social and geographical periphery of Israel and narrow social gaps. This article will examine the following main question: Does access to higher education abet social mobility and narrow social disparities? This article emphasises the changes in the role of academia as a gateway to occupations that allow for high social mobility. Previous research has not focused on this qualitative gap. This article asserts that the increase in enrolment in subjects that do not lead to high income in non-affluent localities may perpetuate the qualitative gaps between these localities and affluent ones. This affects the outputs of the academic system; the quality gaps are beginning to have impacts not only among localities in Israel but also on international comparison tests.
\end{abstract}

Keywords: higher education policy, social gaps, qualitative gaps, accessibility to higher education, accessibility policy

\section{Introduction}

Unprecedented reforms swept the Western world in the second half of the twentieth century, leading to meaningful change in the role of higher education. It changed from a selective, elitist system that trained cadres of future leaders in various fields to an open system that took on new functions, especially high-level professional training. The transformation was accompanied by a perceptible increase in enrolment that demanded general structural change and policy revisions, specifically in budgeting and management. The challenge that policymakers confronted had to do with making the system highly accessible while maintaining the level of research.

The research literature in this field expresses diverse opinions in regard to the policy that higher education may use to attain its goals. Researchers who favour the 'variance' approach say that the new policy has created broader access, led to institutional diversification, and served the needs of the modern economy. Diverse scholastic opportunities are available and new population groups are taking part in higher education and creating a pool for research; therefore, social gaps will narrow. This approach bases itself on studies demonstrating that the those with higher academic education out-earn the unschooled and even those who have a secondary education, and that higher education allows rapid occupational advancement.

Scholars of the 'stratification' approach hold that a policy leading to institutional diversification in a competitive market creates a stratified system because the state cannot support a large number of institutions. Research institutions may sustain damage and the new ones, underbudgeted and burdened by infrastructure deficiency, will be unable to carry out the tasks that higher-education institutions are asked to perform.

From the social standpoint, expanding the system does not necessarily lead to narrowing of social gaps because the upper class knows better how to exploit opportunities than does the lower class. Therefore, system expansion will attract more upper-class individuals while young people in the lower classes will not utilise the change to the same extent. Furthermore, education systems in poorer localities cannot always train candidates to meet the admission requirements of higher-education institutions, forcing young people from these places to enrol in new institutions and low-social-mobility degree programs.

This study proposes quantitative analysis and critical examination of relevant secondary literature. It is based on data from files published by the Israel Central Bureau of Statistics (CBS), CHE, and OECD. The statistical relationship was examined using the Spearman correlation in order to examine two types of data, one variable and the other 
constant. The socioeconomic index is the constant index and the number of learners in several categories is the variable figure. Disparities among localities are examined through the prism of the CBS socioeconomic index, which measures the social level of a local population by combining several separate local indicators: demographic composition, education and schooling, standard of living, employment, and retirement. The measurements were carried out between two clusters of localities: one ranked 1-6 on the socioeconomic index, denoting the lower end, and the other ranked 7-10, indicating the higher.

The article is organised as follows: Part 1 unpacks the various approaches in the literature. Part 2 specifies the research variables and the methodology. Part 3 focuses on the findings. The findings are analysed in Part 4, and the article ends with a summary and main conclusions.

\section{The Policy-Change Debate in the Literature}

Some research literature on reforms in higher education probes the institutional aspect of the matter and its implications for system performance. Research from the social standpoint examines the impact of the reforms on disparities in higher education and in society.

\subsection{The Institutional Aspect}

According to the stratification approach, the institutional hierarchy that is produced by changes is a central factor in creating a system of stratification (Teichler, 1988). Uncontrolled expansion creates unequal competition among institutions, and may actually widen education gaps, instead of creating the desired social change. Public systems operate under public and budgetary supervision, whereas private systems act without limitation. In the competition to attract students, public institutions do not stand a chance. This yields a functional separation that makes the strong stronger and the new and disadvantaged even weaker. Expansion does lead to institutional diversity and answers new social needs, but budget constrains thwart equal competition and give rise to second-class institutions. Well-established schools can invest in excellence and in efforts toward research achievements in order to maintain their hegemonic status. The result is two types of institutions: one prestigious and able to attract the elites, and the other used by the lower classes.

Researchers who subscribe to this view (Farnum, 1990) noted the separatism of elite American universities such as Harvard, Yale, Princeton, and Columbia. Pursuant to reforms carried out at these institutions, these schools, which had started out as institutions that served the children of local elites, emphasised their research excellence in order to attract outstanding students. The American model currently places research universities at the top of the hierarchy, followed by colleges whose role it is to teach and to engage in research that does not require special infrastructure. The third stratum is populated by community colleges that deliberately steer students towards the labour market, while leaving them the option of switching to higher academic education.

In the UK, universities such as Cambridge and Oxford, which cater to the British elite, began to compete with new universities and polytechnic institutes (Jones, 1988). This competition, concurrent with privatisation, left the new institutions far behind and created a systemic stratification that was gradually legitimised by the supervisory entities. Thus, the British Council, which budgets higher education, set up a system of budgeting commensurate with the level of research and teaching (Watson, 1999). Stone (1998) claimed that the privatisation policy created a 'privatisation paradox' - an upturn in state involvement by placing the institutions under increasingly stronger regulation. According to Carr (1998), the reform in the 1970s yielded a binary system: a university track and a new track comprised of polytechnic institutes. Through the latter, the state wished to create access to technical education and reduce its elitist nature. Mid-1980s changes in budget policy led to the establishment of new supervisory institutions - University Funding Councils (UFCs) and Academic Audit Units (AAUs) - to assure the quality of education given and to enhance competition. Due to high costs, the policy was revised again, leading to a new reform in 1992 that did away with this binary institutional system, and transformed the colleges into universities. Comparing changes in Britain, Australia, Japan, France, and the Netherlands, Teichler (1988) concluded that all education systems in these countries were institutionally stratified. Valimaa (1999) identified a conflict between the state, which aspires to change and equal opportunities, and the regulatory entities controlled by the veteran institutions or, at least, influenced by their interests. The conflict leads to a diversified and stratified system.

In Israel, too, demand for higher education and social and political pressures forced CHE to give attention to the matter of comprehensive planning in the 1990s. As a result, the academic system switched from a monolithic structure to the binary dichotomy of universities, stressing research, and academic colleges, which saw academic teaching as their main pursuit. 


\subsection{The Social Aspect}

Some assert that even though the reforms enhanced access and allowed new population groups to join the circle of learners, they may not have furthered mobility and narrowed social gaps because in the twenty-first-century, a bachelor's degree (first degree) is the normative equivalent of a twentieth-century matriculation certificate and, therefore, does nothing to improve social mobility. Another assumption is that whenever something becomes a mass phenomenon, its status appears to fall (Allen \& Allen, 2003). Trow (2003) reasons that academia has assumed new roles that amount, in essence, to training in various fields such as economics and government. Therefore, the increase in enrolment is reflected not in more students doing research, but in larger numbers of persons interested in acquiring a profession and social status. This stands out among students from less-affluent localities, who tend to take less prestigious subjects that can provide an income but contribute less to social mobility. Thus, the increase in enrolment does not narrow social disparities.

According to Collins, the diffusion of higher education created a state of 'credential inflation' (Collins, 1979; Dore, 1976). Enrolment burgeoned, new institutions were opened, and a surfeit of academically trained people resulted. Consequently, those interested in working must show academic credentials even if the job in question does not require them. Academic training that is more sought-after and more impactful on graduates' social status is provided in the fields of exact sciences and technology (OECD, 2018). According to the Maximally Maintained Inequality (MMI) theory, members of the upper class exploit educational and institutional opportunities more effectively than do those of lower class. Thus, the gaps will persist even when strong access exists (Raftery \& Hout, 1993).

\section{The Israeli Case}

When roughly a million people immigrated to Israel from the former Soviet Union and demand for higher education surged, CHE faced public and political pressure to further open the gates to academia. Thus, in December 1993 the government presented a program for the development of colleges that would enrol some 20,000 new students by the end of the century. The structure of the system morphed into a binary system of research universities and academic colleges. The change began with the academisation of colleges and post-secondary institutions and the opening of new branches of Israeli universities, practical-engineering colleges, and teacher-training colleges. In the absence of statutory limits, extensions of foreign universities that operated outside the budgeting system also opened. CHE found it difficult to oversee the massive growth of the institutional array, particularly where overseas branches were concerned. Therefore, in 1998, it amended the CHE Law to include explicit provisions for the activities of such branches. In retrospect, it can be seen that this amendment caused most of the overseas branches to shut down. The few that remained open became Israeli colleges. The growth rate in terms of number of institutions is shown in the following figure. 
Figure 1: Number of Academic Institutions in Israel, 1990-2019

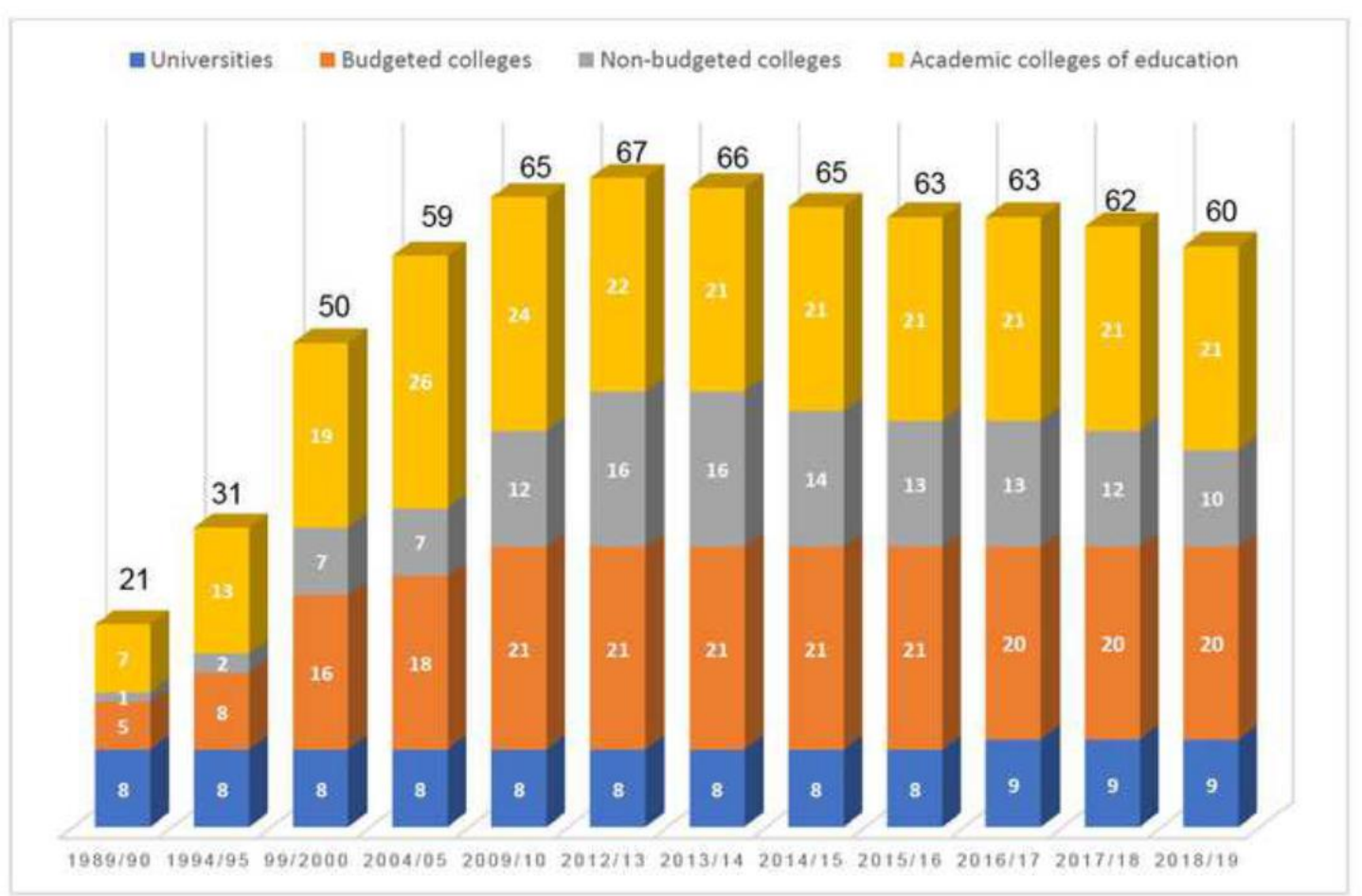

Figure 1. Number of academic institutions in Israel, 1990-2019

The opinions of Israel researchers are divided on this issue as well. According to one approach, the institutional 'variance' that emerged has created an opportunity to meet the economy's steadily growing occupational needs in high-tech and low-tech fields (Walensky, 2010). The technological colleges give training in engineering and technological professions, institutes of art in professions in the arts, music schools in their field, and so on. The diversification allows all candidates to find their place in keeping with their professional aptitude and scholastic ability. It also broadens the pool of learners for advanced degrees and increases the likelihood of successful coping with international scientific competition and challenges.

From the social standpoint, the change made higher education accessible to new population groups. Since the reform, enrolment has increased by a factor of 2.5 or more: in 1990-2917, undergraduate enrolment surged by 281 per cent, enrolment in master's degree programs by 268 per cent, and doctoral programs by 336 per cent. In 2018, the OECD ranked Israel second among member states in its share of persons in the 25-64 age bracket who have post-secondary and academic education (48.5 per cent as against an average of 34 per cent among OECD members).

Researchers who agree with the stratification approach believe that a binary structure such as the one that took shape in Israel is a recipe for discrimination or, at least, for the illusory conviction that this structure can narrow social gaps (Swirsky \& Swirsky, 1997; Swirsky, Connor Attias, \& Zelinger, 2015). The new structure created stratification that affects the quality of academic achievement and even lowers its average level. This allegation is based on reports from a CHE committee that looked into the quality of curricula in the first five years following the reform. The reports gave the opinion that this downturn led to in a decrease in investment in research equipment and in the apportioning of central-government budgets for a situation that had outgrown the country's needs. What came about was a prestigious upper stratum comprised of universities, which benefit from research budgets and well-developed academic infrastructures, and a lower stratum of new institutions, primarily public colleges, which were defined as institutions for teaching and not for research. The process received legitimacy from the regulatory bodies, as happened in the UK. This stratification also exists among universities and among colleges. In the college stratum, there is stratification between institutions that receive public budgets and those that do not. In the university stratum, stratification exists between special-purpose institutions defined as 'target universities' (Ben-Gurion University, Bar-Ilan University, and Haifa University), which were meant to make higher education accessible to the periphery, 
and research universities (Hebrew University, Tel Aviv University, and the Technion) (Yogev, 2000).

A 2016 OECD study found Israel among the leaders in the rate of overeducated workers, meaning that education does not assure a higher wage than that earned by persons who do the same work and lack higher education (Katz, 2017), Furthermore, higher education in Israel does not contribute to the average Israel worker's labour productivity and human capital, as reflected in relatively low PIAAC scores. (Note 1)

Additional studies show that inequality among social groups at the start of higher education persists even though the system has expanded. There are two dimensions of inequality: vertical and horizontal. Vertical inequality is manifested in continuing and advanced-degree studies; horizontal inequality reflects differences between more prestigious and less prestigious institutions in terms of types of diplomas and subjects studied. Horizontal inequality also occurs when graduates of universities have an income advantage over those graduating from colleges (Shwed \& Shavit, 2006). Even though students from less-affluent localities have made gains in access, the qualitative gaps between them and counterparts from well-off localities have been widening. Students from groups that are disadvantaged in terms of social class, nationality, or social sector enrol in less prestigious programs of study (Ayalon \& Yogev, 2006; Getz \& Dar, 2007) whereas those from the upper class seize the opportunity to earn prestigious degrees from highly regarded institutions (Raftery \& Hout, 1993). This tendency even encourages employers to adopt indicators of graduates' quality by the institution from which they graduated, and to perceive a prestigious school as providing better training for the world of work (Barzilai-Shaham \& Yaish, 2015).

In the vertical dimension, candidates from the non-immigrant Jewish population enrol in higher education at higher rates than do young people from the social periphery and, in particular, than Israeli Arabs. On the horizontal plane, it is found that those from the former Soviet Union have a good chance of enrolling in programs of study that lead to higher income than young people of Mizrahi, (Note 2) Arab, or Ethiopian origin and even of mixed Ashkenazi-Mizrahi origin (Feniger et al., 2013).

An examination of first-year enrolment shows a larger percentage of students in the Jewish primary and secondary education system who come from localities in the three highest clusters on the socioeconomic index and lower rates among Jews and Arabs who live in localities in the three lowest clusters. The focal point of this inequality, in the opinion of the authors of the study, is the pyramid structure of the education system, namely: the higher the level, the smaller the share of those who advance to the next level. Only one-third of the relevant age group reaches the top. Within the education system, a difference exists between those eligible for a matriculation certificate that suits the requirements of academia and one that does not. A relation is also found between income outlook and specialisation in high school: Students who took a scientific 'major' in high school are more likely to enrol in academic disciplines that lead to high income, such as engineering and the exact sciences, than are students who specialised in social sciences and education. According to the reporters of these findings, the expanded system replicated the differential structure of opportunities that the primary and secondary education system offers. Although non-budgeted colleges lowered their admission barriers, the connection between economic wherewithal and access to higher education persists and has gathered strength (Dagan-Buzaglo, 2007).

\section{Goals, Hypotheses, and Methodology of the Study}

\subsection{Goals of the Study}

The study explores the following questions:

Has CHE's policy of enhancing access to higher education, passed two decades ago, attained its objectives?

Assuming that the quality of outcomes in a growing academic system declines, does this affect the quality disparities among localities and, ultimately, the narrowing of social gaps in Israel?

Has CHE's policy affected the quality of system outcomes on international indices?

\subsection{Research Hypotheses}

CHE's access policy has facilitated the entry of population groups from localities in the six lowest levels of the socioeconomic index, but the disparities between these localities and those at higher levels persist. It is assumed that the gap originates in schools in non-affluent localities (Feniger et al., 2013).

Given the importance of higher education for participation in the job market and social mobility (Barzilai-Shaham \& Yaish, 2015), the increase in the share of students in localities in the six lowest clusters who pursue higher studies in fields that do not lead to social mobility may perpetuate the qualitative gaps between the sets of localities. 
The new roles of higher education have bolstered the numbers of those who care most about acquiring a profession and are less interested in doing research. This phenomenon affects Israel's research outputs and is reflected in international indices published by the OECD.

These hypotheses rest on the previously-mentioned diminished value of a bachelor's (first) degree, meaning that the increase in enrolment does not attest to the quality of the system's outcomes. The upturn in enrolment centres on students who are interested in acquiring a profession and social status, and less on those interested in conducting research. This phenomenon is stronger among students who live in less-affluent localities; therefore, the upturn in enrolment in these localities will not narrow social gaps between these localities and more affluent ones.

Another hypothesis is based on the underlying assumption of the MMI theory: the affluent exploit opportunities that high-tuition institutions offer them, whereas those from the less-affluent classes attend unprestigious institutions (Raftery \& Hout, 1993). As slots in prestigious schools are reserved for the affluent while the less-well-off are unable to attend, the disparities are perpetuated despite improved access (Ayalon \& Yogev, 2006; Getz \& Dar, 2007).

\subsection{Methodology}

The study is mainly quantitative and based on data collected from files available on the CBS, CHE, and OECD websites. The statistical relations were tested using the Spearman coefficient because one of the datasets, that of the socioeconomic index, is constant, and the other, student enrolment in several categories, is variable.

Disparities among localities are tested by the CBS socioeconomic index, which measures the social level of the local population through a combination of five local indicators: demographic composition, education and schooling, standard of living, employment, and retirement. Two clusters of localities were measured: one ranking low in the socioeconomic index and another in the higher ranges.

The qualitative disparities or the gaps in horizontal inequality were examined by means of two variables:

Number of individuals studying for research-based degrees as against those studying for professional degrees, in two groups: those who live in localities ranked 7-10 in the socioeconomic index and those from localities in the 1-6 cluster.

Number of students taking STEM (science, technology, engineering, and mathematics) and ICT (information and communication technologies) subjects as against those in the social sciences and especially education and teaching. According to OECD publications, the STEM and ICT majors attract students who wish to parlay high income and social mobility into social advancement.

Education studies were chosen as a comparative variable because they confer professional status on those who are interested in acquiring a profession but may not wish to go on to advanced research studies. The education profession is believed to award scant social mobility because it pays poorly and is often chosen by default. Researchers have found that the average score on the psychometric test achieved by students enrolled in colleges of education is, on average, lower than over 61 per cent of all persons taking this exam (Ben-David, 2017-2018).

The following quantitative data were examined:

The per cent of new first-degree students aged 20-24 in 2017, according to types of localities.

The per cent of new first-degree university students of the same age group in 2017. These data are instructive of the intent to take advanced research-intensive subjects as against students who enrol in colleges, which are not defined as research institutes.

The per cent of new first-degree students in the same age group in 2017 at academic colleges of education, as compared with the percent of students taking high-tech or research subjects in various localities.

The per cent of new first-degree students who dropped out in the 2016 academic year and attended no academic institution in 2017.

The per cent of degree holders aged 26-50 in 2016, by locality.

\section{Findings --- The Complexity of Israel's Public Higher-Education Policy}

The number of students in Israel's northern and southern districts (Appendix, Table 1) indicates the distribution of higher education. The share of students in the southern district rose by 70 per cent between 1990 and 2020. In the northern district, where no students were recorded in 1990, the rate became 9.5 per cent at the first-degree level.

The share of Arab students in all districts climbed from 8.3 per cent of all students in 2000 to 15.2 per cent in 2017 
and 17.9 per cent in 2019. Their representation in 2017 was 6.5 per cent among first-degree candidates, 13.6 per cent of those studying for a master's degree, and 7.2 per cent at the level of Ph.D. studies.

The number of ultra-Orthodox Jewish students studying for academic degrees increased by seventeen times between 2000 and 2017-from 560 to 9,400. In 2020, 13,100 ultra-Orthodox students were pursuing a degree at some level, an increase of 5.8 per cent.

The CHE policy set in motion a long-term trend in which the share of enrolment in first-degree programs has been falling - from 85 per cent in 1990 to only 38.6 per cent in 2020 (Appendix, Table 2). The non-budgeted colleges also showed a downward trend, their share in first-degree programs dropped from 19.4 per cent in 2015 to 18 per cent in 2020. Budgeted colleges saw a mild increase in total enrolment but their number of first-degree students also decreased (Appendix, Table 3). The population of new students at the universities in 2019 grew by 7.6 per cent as compared to 4.2 per cent at colleges, with a steeper increase at budgeted colleges (5.2 per cent) and a 1.5 per cent decline at colleges of education.

Unlike those enrolled in first-degree studies, the number of master's degree candidates has been slipping in recent years. Only non-budgeted colleges and academic colleges of education recorded mild increases (Appendix, Table 4). The rate of change in master's degree enrolment between 2010 and 2017 was 0.8 per cent at universities as compared to 7.9 per cent at colleges during the same years. The trend continued in 2019 and, as shown about in regard to first-degree studies, the share of universities at the master's degree level also fell during these six years, from 71 per cent to 63 per cent. A major decrease occurred in research-based master's degrees - only 25.7 per cent of all university degrees were at this level in 2019, as compared to 34 per cent in 2008. The established universities-Hebrew University, the Technion, and the Weizmann Institute - also saw a decline. The trend in degree recipients in the natural sciences is different: here the percent in research tracks remained stable at most institutions (Appendix, Table 5).

The upturn in master's degree enrolment at colleges may reinforce this trend because these institutions have very few research departments and the CBS data for 2010-2018 show a one-in-eight chance of university graduates going on to research-based master's degree programs, as compared to 1:43 among graduates of academic colleges and 1:62 of those at colleges of education. In the natural sciences, one of every two or three first-degree graduates from universities go on to research-based master's degree studies.

\subsection{Vertical Inequality}

Notwithstanding the perceptible upturn in enrolment in the districts at large, enrolment growth in the geographic and social periphery has slowed. The main reason is a 4 per cent decline in the number of those embarking on higher education among high-school graduates in 2010-2011, as opposed to a 6 per cent increase in 2001-2010. The share of first-year students in academic settings peaked in 2013 at 49.4 per cent and fell to 47.8 per cent in 2016 and 47 per cent on average since then. Among high-school graduates in less-affluent localities, the average is lower (Appendix, Table 6).

In fact, the share of those in cluster 1-4 on the socioeconomic index who advance to academic studies has not changed since the reform in the 1990s: 32.1 per cent in 1994, as compared to 54.4 per cent in cluster 5-6 and more than 64 per cent in cluster 7-10. In 2019, the rates of advancement were 32.4 per cent in cluster 1-4, 47.8 in cluster $5-7$, and 62.8 per cent in cluster 8-10.

The rates are lower in the Arab education system than the Jewish one. In 2001, the rates in the Arab education system were: 22.1 per cent of high-school graduates in cluster 1-4, 30 per cent of those in cluster 5-7, and 16.7 per cent in those in cluster 8-10 went on to academia; 75.1 per cent did not move on to higher studies at all. The rates rose steadily from then on: to 27.6 per cent in cluster $1-4,33.8$ per cent in cluster 5-7, and 41.5 per cent in cluster 8-10 in 2016, with 66.6 per cent not advancing to higher studies.

The distribution of students by socioeconomic cluster and type of institution shows a trend in which students from low clusters were more likely to attend budgeted colleges (Figure 2): 
Figure 2: Distribution of High-School Students by Socioeconomic Cluster, 2017/18

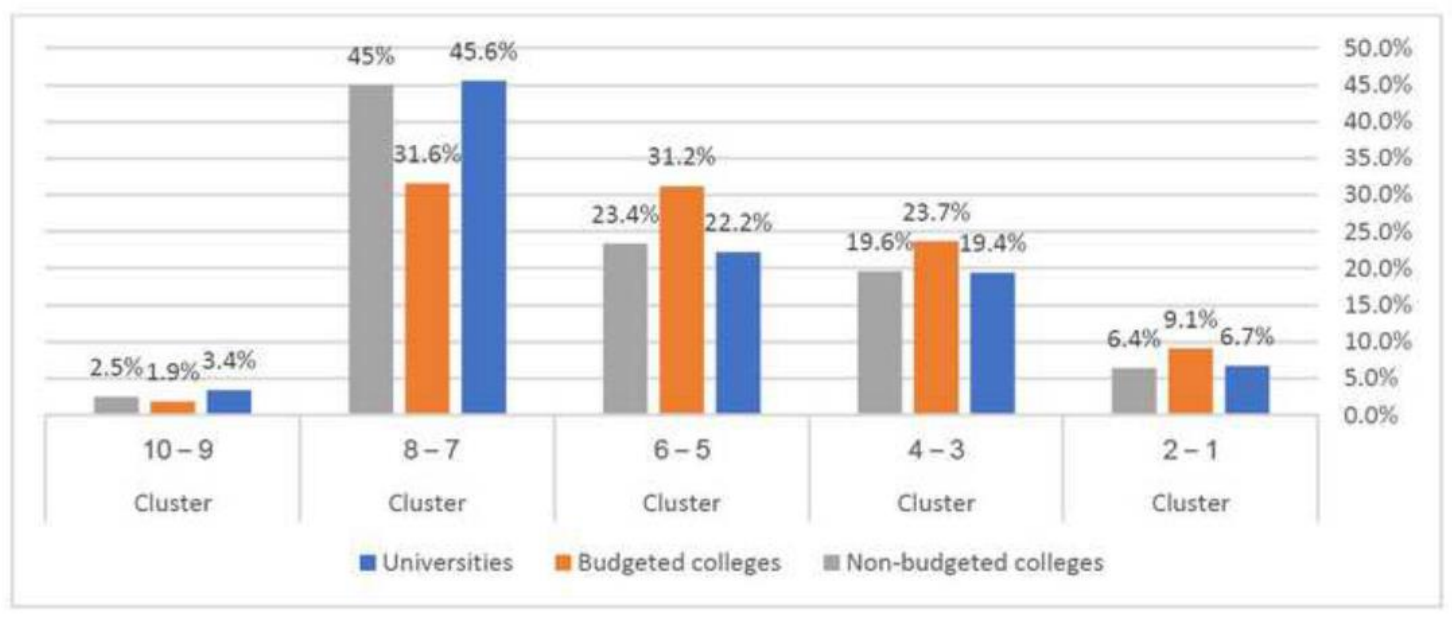

Figure 2. Distribution of high-school students by socioeconomic cluster, 2013/14

Figure 3: Distribution of High-School Students by Socioeconomic Cluster, 2019/20

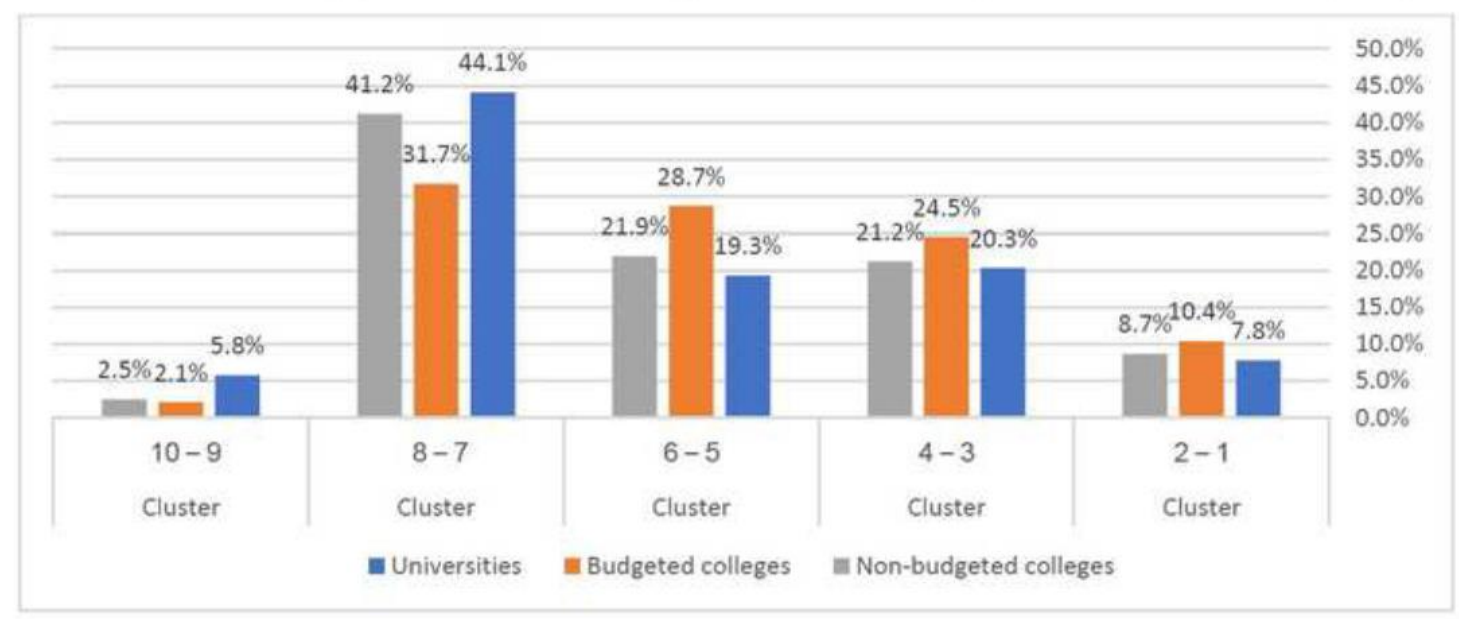

Figure 3. Distribution of high-school students by socioeconomic cluster, 2017/18

In 2014, most students in clusters 1-4 attended public colleges and 28 per cent attended universities. In 2018 , the respective rates were 33.4 per cent and 26.8 per cent. The share of students in clusters 1-4 who attended non-budgeted colleges rose from 22 per cent in 2014 to 26.8 per cent in 2018.

Students from localities ranked 7-10 were more prevalent at universities and non-budgeted colleges in 2014, with 35 per cent of students in this cluster enrolled in universities and 32 attending non-budgeted colleges. The trend persisted in 2019-2020 as shown in Figure 4: 
Figure 4: Distribution of High-School Students by Socioeconomic Cluster, 2019/20

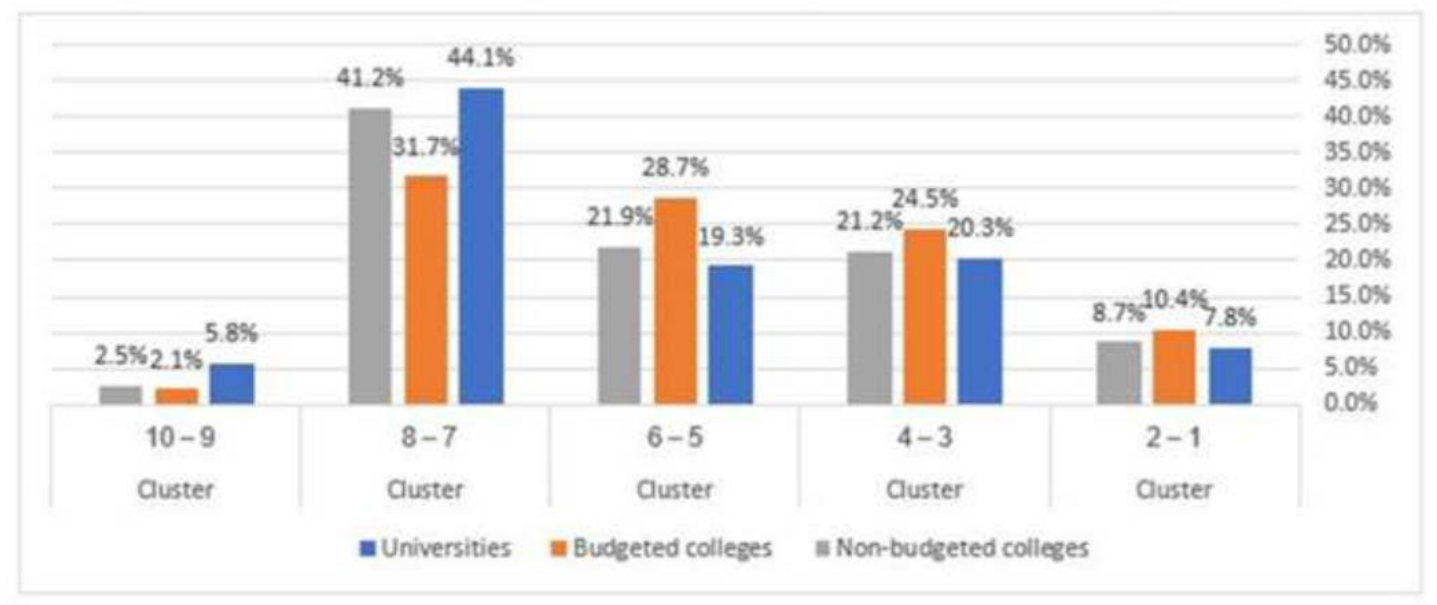

Figure 4. Distribution of high-school students by socioeconomic cluster, 2019/20

\subsection{Horizontal Inequality - Qualitative Disparities}

As stated, the qualitative disparities were examined in terms of the percent of students in research degree programs and STEM majors, according to two clusters of localities: levels 1-5 in the socioeconomic index and levels 6-10.

\subsubsection{Disparities in Candidates for Research-Based Degrees}

Above we noted an increase in master's degree candidates at colleges and suggested this will widen the gap between master's degree students involved in research and those going for non-research degrees, given the paucity of research departments at the colleges. Indications of this may be seen in the number of Ph.D. candidates: a 0.8 per cent annual average change in 2000-2010 as compared to 3.5 per cent in the number of master's degree candidates. The number of those earning Ph.D. degrees increased by only 49 per cent from 2017 to 2016.

Israel's advantage in first-degrees narrows steadily when the data on advanced degrees are considered. Israel's average rate of people in the under-30 group with first-degrees was 41 per cent, as compared with an OECD average of 36 per cent and only 33 per cent in the EU22 countries. The gap narrows as the level of degree rises: The average of those in the under-thirty-five age group with master's degrees was 18 per cent in Israel, as compared with 15 per cent in the OECD countries, and 17 per cent in the EU22 countries. At the doctoral level, the average in Israel for that age group was 1.4 per cent, the same as in the OECD countries, and compared to 1.5 per cent in the EU22 countries. When students in Israel who are non-residents are excluded, the average falls to 1.5 per cent as compared to 1.8 per cent in the OECD member states and 2.0 per cent in EU22 (OECD, 2015).

\subsubsection{Disparities in Enrolment in Leading Majors—National Level}

The OECD has found that graduates in STEM subjects tends to be older upon joining the labour market than those in other academic disciplines and earn more than the OECD-wide average (OECD, 2017). For this indicator, Israel is not positioned as high as it is in first-degree recipients (Appendix, Table 7). In engineering, the gap is steadily narrowing because enrolment in technological colleges is growing. The share students in these colleges who were enrolled in engineering studies climbed from 41 per cent of all those taking these subjects in 2000 to 45 per cent by 2017. Non-budgeted colleges make no contribution in this respect because they do not have engineering programs.

The situation in other STEM subjects is different. In the past four years, the share of students in Israel studying mathematics and technology, among those enrolled in all STEM subjects, rose by only 0.7 per cent, physical sciences slipped by 0.4 per cent, and the research-intensive biological sciences went up by only 0.1 per cent (Appendix, Table 8). In 2017, a change in ICT enrolment occurred due to a deliberate policy on the part of the National Council and CHE, which diverted resources to the goal of increasing university enrolment in these fields. The share of ICT enrolment came to 8.1 per cent of all first-degree students in 2017 as opposed to 5 per cent in 2015. This change in trend had no effect on students from non-affluent localities, as shown below. 


\subsubsection{Quality Disparities Between Affluent and Less-Affluent Localities in Studies of Leading Subjects}

The gaps between affluent and less-affluent localities persisted in both quantitative and qualitative parameters. To test for a connection between locality socioeconomic ranking and field of studies in 2017, I performed an analysis using the Spearman coefficient. It revealed a statistically significant negative relation between socioeconomic ranking and education studies and teacher training $(r=.757, \mathrm{p}>.001)$. Namely, statistically significant positive relations were found between local socioeconomic ranking and the other fields of study: a significant positive relation between local socioeconomic ranking and engineering and architecture studies $(\mathrm{r}=.679, \mathrm{p}<.001)$ and between local socioeconomic ranking and studies of physiological science $(\mathrm{r}=.527, \mathrm{p}<.001)$, mathematics and computer science $(r=.43, \mathrm{p}<.001)$, and biological science $(\mathrm{r}=.177, \mathrm{p}<.01)$. As for the other fields of study (i.e., those outside the natural sciences), the higher a locality's socioeconomic ranking is, the more frequently local residents enrol in scientific and engineering studies. Table 9 (in the Appendix) presents the percentages of enrolment in the fields of study that were examined in selected high-, middle-, and low-ranking cities.

A significant positive correlation was found between a locality's socioeconomic ranking and the percent of its residents who attend universities $(r=.467, \mathrm{p}<.001)$. Namely, the higher a locality's socioeconomic rankings, the larger the percent of its residents who attend universities. A similar positive relation was found between socioeconomic index and percent enrolled in non-budgeted colleges $(r=.258, \mathrm{p}<.001)$, i.e., the higher the socioeconomic index, the larger the percent of students at non-budgeted colleges. A significant negative relation was found between a locality's socioeconomic index and the percent of its students who attend budgeted colleges $(r=$ $.231, \mathrm{p}<.001)$. That is, the higher the socioeconomic index, the smaller the share of enrolment in budgeted colleges. A similar relation was found among those attending colleges of education and teacher-training institutions of all kinds, and not only at the first-degree level as shown above.

Testing the percent of students in a locality according to enrolment in universities and in teacher-training institutions, we found significant relations between affluent localities (those in socioeconomic cluster 6-10) and those ranked 1-5. The same was detected in the share of students in academic programs these localities in 2015/16. Several of the variables examined are presented in Table 12. The upward trend of the data shown in Table 10 (Appendix) is impressive. The results of the Spearman test indicate the existence of a powerful and significant positive relation between socioeconomic index and percent of students in academic degree programs in a locality $(r=.895, \mathrm{p}<.001)$. The higher a locality's socioeconomic index, the higher the percent of its residents who are enrolled in academic studies. The results of the Spearman test point to a significant negative correlation between socioeconomic index and percent of enrolment in humanities and social science $(\mathrm{r}=-.431, \mathrm{p}<.001)$. Thus, the higher a locality ranks on the socioeconomic index, the smaller the percent of its residents who study humanities and social science. The Spearman test reveals a significant positive relation between a locality's socioeconomic ranking and the percent of its residents who study science and engineering $(\mathrm{r}=.431, \mathrm{p}<.001)$. That is, the higher a locality ranks on the socioeconomic index, the higher the percent of its residents who engage in science and engineering studies.

\subsubsection{Dropout Rates by Students' Places of Residence}

Another indicator of significant differences among localities is the dropout rate. On the one hand, people living in the periphery have access to higher education. On the other hand, their continued studies are not assured, due to inequality that goes back to high school. The dropout rate among students from these localities who attend teacher-training institutes and non-budgeted colleges is much higher than the rate among those who enrol in universities and budgeted colleges. The explanation lies in the types of students who apply to each class of institution: universities and budgeted colleges attract students who have higher admission credentials than do those who apply to colleges of education and non-budgeted colleges (Appendix, Table 11). The higher the score on the psychometric exam, the lower the likelihood of dropping out. Similarly, the more units in mathematics that students earn on their matriculation exam, the less likely they are to drop out. Neither outcome has any significant relationship with enrolment in colleges of education and non-budgeted colleges.

Another indicator that affects the dropout rate is parents' education; the impact is seen even when only one parent has higher education (Appendix, Table 12). Examination of dropout rates in affluent and less-affluent localities shows a clear correlation between a locality's socioeconomic ranking and its residents' dropout rate.

Given that the percent of academic enrolment is lower in localities ranked 1-5 than in those ranked 6-10, the dropout indicator shows a widening of the gap between the groups of localities. The national average dropout rate and the average rate among localities reinforces this assumption. 


\section{Discussion}

From the institutional standpoint, the CHE policy created greater diversity and allowed students to gain admission on the basis of different credentials. Therefore, one may say that the CHE's initial objectives have been attained. Nevertheless, this policy, from its outset, created stratification because the public colleges, operating without research budgets and defined as undergraduate teaching institutions, remained at the bottom of the hierarchy. The policy of expansion that began with the academisation of various institutions was typified by an elitist approach that segregated the types of diplomas that the colleges would award. Thus, institutions of education were authorised to grant a special-purpose degree - the B.Ed.-and technological colleges were authorised to issue a general engineering degree, the B.Tech. Alongside these institutions, private colleges were opened in an unregulated manner, offering degrees from foreign universities and focusing on attractive subjects such as law, leaving the public colleges behind. As the MMI theory claims, students from affluent localities were better able to take advantage of the opportunity than were their counterparts from less-affluent places.

After the public colleges put up a lengthy struggle, the policy was revised. Now technological colleges are allowed to award engineering degrees of the conventional university type, and other colleges began to offer master's degree programs in both research and non-research tracks. A struggle by the academic staff yielded a first-ever employment agreement in 2012 that offered them the opportunity to conduct some components of research.

Although the struggle spared the structure of the system from extreme stratification, further revision of the CHE's policy is needed to avert the possibility of losing ground as measured by international indices. The fact that Israel's universities are defined as research institutions yet award mainly non-research degrees, while its colleges engage in research without having the infrastructure to do so will lower Israel's performance in these indices. This clashes with Yogev's (2000) view because the percent of candidates for non-research degrees is large even at the universities that he defines as research institutions, in contrast to those that he classifies as target universities.

From the social standpoint, it is notable that the percent of students from less-affluent localities has hardly changed since the system was liberalised. In 1994, 32.1 per cent of residents in of localities in socioeconomic index cluster 1-4 went on to higher studies; 34 per cent did so in 2016. In the higher socioeconomic rankings, too, no change occurred during this time: the percentage was equally high before and after. Thus, the hypothesis that the system has perpetuated the disparities between the two classes of localities is corroborated.

The numerical increase in enrolment from less-affluent localities suggests, to some extent, that the narrowing of social gaps is illusory. Our examination of subjects of study shows a statistically significant positive relation between socioeconomic ranking and percent of enrolment in universities and in non-budgeted colleges. A significant negative correlation was found between socioeconomic ranking and percent of enrolment in teacher-training colleges and budgeted colleges. As the MMI theory postulates, students from affluent localities are better able than those from weak localities to utilise the opportunities that have come about. The percent of enrolment in high-mobility research-intensive subjects, which are taught in universities to populations from high-ranking localities, also indicates the existence of horizontal inequality.

The dropout rate rises in tandem with students' origin in localities that rank low on the socioeconomic index and exceeds the national average by far. Parents' education also affects the dropout rate and points to difficulty in eliminating disparities even if the second generation wants to improve its social standing. Therefore, access to higher education in these localities may be illusory.

Another illusion at the national level is found in enrolment in master's degree programs: although the number of students has increased, two-thirds of them go for non-research degrees. In this indicator, too, the percent of non-research candidates from non-affluent localities is high.

\section{Summary and Conclusions}

In the absence of real change in the number of high-school students in peripheral localities who earn matriculation certificates, and assuming no large-scale immigration, Israel's academic system has gone as far as it can at the first-degree level. The only way it can continue expanding is by increasing enrolment from the social and geographic peripheries, including the ultra-Orthodox and Arab sectors, which are still severely underrepresented relative to their share in the population, as stated at the beginning of this article.

CHE needs to revise its policy on budgeting higher-education institutions in favour of promoting research-intensive subjects. An increase in enrolment in the natural sciences may assure an upturn in doctoral graduates and better research outcomes. The change should be accompanied by a new and more exacting definition of the institutions' roles: Colleges should focus on improving access and providing professional education along with applied research; 
universities, in turn, should withdraw from these subjects and concentrate on research disciplines.

This study makes a significant contribution by revealing new disparities among localities and exposing the illusions that unregulated expansion of the system has created. It is not quantity but quality that will help to narrow social gaps. The periphery needs new subjects that offer high social mobility, as OECD studies show. CHE has not adequately internalised the global change that has occurred in the impact of fields of study on social mobility. Recently, social and political pressure by the CHE has stimulated enrolment in technological and ICT fields, but not in the periphery.

\section{References}

Allen, C. M., \& Allen, W. B. (2003). Habits of mind. Transaction.

Ayalon, H., \& Yogev, A. (2005). Field of study and students' stratification in an expanded system of higher education: The case of Israel. European Sociological Review, 21, 227-241. https://doi.org/10.1093/esr/jci014

Barzilai-Shaham, Y., \& Yaish, M. (2015). The influence of an academic institution on its graduates' employment opportunities. Israeli Sociology: Journal for Israeli Social Research, 15(2), $56-75$ (in Hebrew).

Ben-David, D. (2017-2018). Shoresh guide: Education in Israel and its impact. Shoresh Institution for Socioeconomic Policy Research (in Hebrew).

Carr, F. (1998). The rise and fall of the polytechnics: Explaining change in British higher education policy making. Policy and Politics, 26(3), 273-291. https://doi.org/10.1332/030557398782213629

Collins, R. (1979). The credential society: An historical sociology of education and stratification. Academic Press.

Dagan-Buzaglo, N. (2007). The right to higher education in Israel: A legal and budgetary view. Adva Center (in Hebrew).

Dore, R. (1976). The diploma disease: Education, qualification and development. George Allen \& Unwin.

Farnum, R. (1990). Prestige in the Ivy League: Democratization and discrimination at Penn and Columbia, 1890-1970. In P. W. Kingston, \& L. S. Lewis (Eds.), The high-status track: Studies of elite schools and stratification (pp. 75-103). State University of New York Press.

Feniger, Y., Ayalon, H., \& Mcdossi, O. (2013). Research report: Access to higher education among young people from the social periphery in Israel. Submitted to Gandyr Fund, March 2013 (in Hebrew).

Getz, S., \& Dar, Y. (2007). Learning ability, socioeconomic status, and student placement for undergraduate studies in Israel. Higher Education, 54, 41-60. https://doi.org/10.1007/s10734-006-9045-1

Jones, D. R. (1988). The origins of civic universities. Routledge.

Katz, O. (2017). A surfeit of higher education in Israel. Kohelet Forum, Policy Paper 36 (in Hebrew).

OECD. (2015, 2017-18). Education at a glance: OECD indicators, executive summary. Author.

Raftery, A., \& Hout, M. (1993). Maximally maintained inequality: Expansion, reform and opportunity in Irish education 1921-75. Sociology of education, 66, 41-62. https://doi.org/10.2307/2112784

Shwed, U., \& Shavit, Y. (2006). Occupational and economic attainments of college and university graduates in Israel. European Sociological Review, 22, 431-442. https://doi.org/10.1093/esr/jcl006

Stone, D. (1998). Principles and Pragmatism in the 'Privatization of British Higher Education. Policy and Politics, 26(3), 255-273. https://doi.org/10.1332/030557398782213674

Swirsky, S., \& Swirsky, B. (1997). Higher education in Israel. Adva Center (in Hebrew).

Swirsky, S., Connor Attias, E., \& Lieberman, A. (2018). Social snapshot 2018. Adva Center (in Hebrew).

Swirsky, S., Connor Attias, E., \& Zelinger, R. (2015). Social Snapshot 2015. Adva Center (in Hebrew).

Teichler, U. (1998). Changing patterns of the higher education system: The experience of three decades. Jessica Kingsley.

Trow, M. (2003). On mass higher education and institutional diversity. Retrieved from https://www.neaman.org.il/EN/Mass-Higher-Edu-Institutional-Diversity-Uni-Edu-HR

Valimaa, J. (1999). Managing a diverse system of higher education. In M. Henkel, \& B. Little (Eds.), Changing relationships between higher education and the state (pp. 23-41). Jessica Kingsley. 
Watson, D. (1999). Decoding dearing on diversity. In M. Henkel, \& B. Little (Eds.), Changing relationships between higher education and the state (pp. 37-325). Jessica Kingsley.

Wilensky, A. (2010). Is there a contradiction between improving higher-education quality and continued diffusion and expansion?. Presentation at Ashkelon Academic College conference (in Hebrew).

Yogev, A. (2000). Stratification in Israel's universities and its implications for higher-education policy. Israeli Sociology: Journal for Israeli Social Research, 2(2), 481-498 (in Hebrew).

\section{Notes}

Note 1. Programme for the International Assessment of Adult Competencies, a survey of adults' labour-market skills.

Note 2. Jews of Middle East/North African background.

\section{Appendix: Tables}

Table 1. Percent of First-Degree Students, by District in Which Institution Is Located, Selected Years

\begin{tabular}{rlll}
\hline & $\mathbf{1 9 8 9 / 9 0}$ & $\mathbf{1 9 9 9 / 2 0 0 0}$ & $\mathbf{2 0 1 9 / 2 0}$ \\
\hline Jerusalem & 22.7 & 15.5 & 15.5 \\
\hline Northern & - & 5.3 & 5.3 \\
\hline Haifa & 21.7 & 17.9 & 17.9 \\
\hline Central & 4.1 & 15.9 & 15.9 \\
\hline Tel Aviv & 42.8 & 31.5 & 31.5 \\
\hline Southern & 8.7 & 13.9 & 13.9
\end{tabular}

Not including students enrolled in the Open University.

Table 2. First-Degree Students by Type of Institution, Selected Years

\begin{tabular}{rllllll} 
& Total, N & Pct. & Univ. & $\begin{array}{r}\text { Acad. } \\
\text { colleges, incl. } \\
\text { extensions }\end{array}$ & Non-budgeted & $\begin{array}{r}\text { Educ. } \\
\text { colleges }\end{array}$ \\
colleges \\
\hline $1989 / 90$ & 55,246 & $100 \%$ & 85.0 & 3.4 & 3.0 & 8.6 \\
\hline $1999 / 2000$ & 126,896 & $100 \%$ & 52.7 & 19.5 & 12.5 & 15.2 \\
\hline $2009 / 10$ & 178,739 & $100 \%$ & 37.2 & 33.0 & 18.5 & 11.3 \\
\hline $2014 / 15$ & 191,691 & $100 \%$ & 33.8 & 34.0 & 19.4 & 12.8 \\
\hline $2016 / 17$ & 191,241 & $100 \%$ & 38.7 & 29.5 & 18.4 & 13.4 \\
\hline $2019 / 20$ & 197,546 & $100 \%$ & 38.6 & 30.0 & 18.0 & 13.4 \\
\hline
\end{tabular}


Table 3. First-Year Enrollment in Higher-Education Institutions by Type of Institution, Selected Years

\begin{tabular}{|c|c|c|c|c|c|c|}
\hline \multirow[t]{2}{*}{ Total } & \multicolumn{2}{|r|}{ Universities } & \multicolumn{2}{|c|}{ Academic colleges } & \multicolumn{2}{|c|}{$\begin{array}{r}\text { Academic colleges of } \\
\text { education }\end{array}$} \\
\hline & First year & $\begin{array}{r}\text { Pet. } \\
\text { change, } \\
2009 / 10- \\
2016 / 17 \\
\end{array}$ & First year & $\begin{array}{r}\text { Pct. } \\
\text { change, } \\
2009 / 10- \\
2016 / 17 \\
\end{array}$ & First year & $\begin{array}{r}\text { Pet. } \\
\text { change, } \\
2009 / 10 \\
2016 / 17 \\
\end{array}$ \\
\hline $2009 / 10$ & 22,982 & & 26,384 & & 5,084 & \\
\hline $2015 / 16$ & 23,557 & & 28,097 & & 7,408 & \\
\hline $2016 / 17$ & 24.011 & 0.5 & 27,844 & 0.8 & 8,158 & 5.7 \\
\hline $2018 / 19$ & 19,332 & & 26,817 & & 7,583 & \\
\hline
\end{tabular}

Table 4. Master's Enrollment in Colleges and Universities, 2013/14 and 2019/20

\begin{tabular}{|c|c|c|c|c|c|c|c|c|c|c|}
\hline & \multirow{2}{*}{$\begin{array}{l}\text { Total } \\
\text { M.A., } \\
\text { all inst. }\end{array}$} & \multirow{2}{*}{$\begin{array}{l}\text { Total, } \\
\text { univ. }\end{array}$} & \multirow{2}{*}{$\begin{array}{r}\text { Share } \\
\text { of } \\
\text { M.A. } \\
\text { enroll- } \\
\text { ment }\end{array}$} & \multirow[b]{2}{*}{ Total } & \multirow[b]{2}{*}{$\begin{array}{r}\text { Gen-eral } \\
\text { college }\end{array}$} & \multirow[b]{2}{*}{$\begin{array}{l}\text { Pct. of } \\
\text { M.A. } \\
\text { students }\end{array}$} & \multirow[b]{2}{*}{ Non-budgeted } & \multirow[b]{2}{*}{$\begin{array}{r}\text { Share of } \\
\text { M.A. } \\
\text { enroll- } \\
\text { ment }\end{array}$} & \multicolumn{2}{|c|}{ Academic colleges } \\
\hline & & & & & & & & & $\begin{array}{r}\text { Educ. } \\
\text { colleges }\end{array}$ & $\begin{array}{r}\text { Share of } \\
\text { M.A. } \\
\text { enrollment }\end{array}$ \\
\hline $2013 / 14$ & 54,738 & 38,855 & $71 \%$ & 15,883 & 15,883 & $6.2 \%$ & 7,788 & $14.2 \%$ & $14.2 \%$ & $12 \%$ \\
\hline $2019 / 20$ & 61,044 & 38,603 & $63.2 \%$ & 22,441 & 22,441 & $8 \%$ & 9,584 & $15.7 \%$ & $15.7 \%$ & $13.0 \%$ \\
\hline
\end{tabular}

Table 5. Master's Degree Recipients at Universities and, thereof, in Natural Sciences

\begin{tabular}{rrrrrrr}
\hline Institution & $\begin{array}{r}\mathbf{\%} \text { of } \\
\text { recipients, } \\
\text { total }\end{array}$ & $\begin{array}{r}\text { \% in nat. } \\
\text { sciences }\end{array}$ & $\begin{array}{r}\text { \% of } \\
\text { recipients, } \\
\text { total }\end{array}$ & $\begin{array}{r}\text { \% in nat. } \\
\text { sciences }\end{array}$ & $\begin{array}{r}\text { \% of } \\
\text { recipients, } \\
\text { total }\end{array}$ & $\begin{array}{r}\text { \% in nat. } \\
\text { sciences }\end{array}$ \\
\hline Hebrew U. & 42.4 & 84.7 & 40.1 & 87.6 & 37 & 78.3 \\
\hline Technion & 60 & 75.4 & 52.2 & 97.1 & 56.5 & 98 \\
\hline Tel Aviv & 34.2 & 85.7 & 23.4 & 82 & 23.7 & 66 \\
\hline Bar-Ilan & 20 & 90.6 & 14.4 & 75.5 & 16.7 & 71.3 \\
\hline Haifa & 28 & 50 & 34.5 & 47.1 & 17.2 & 42.7 \\
\hline Ben-Gurion & 34.1 & 100 & 33.4 & 99.3 & 35.2 & 100 \\
\hline Weizmann & 100 & 100 & 80.1 & 100 & 82 & 100 \\
\hline & & & & & & \\
\hline
\end{tabular}


Table 6. Tracking of Advancement to Higher Studies, Jewish System, within Eight Years of High-School Graduation (Selected Years)

\begin{tabular}{rrrrr}
\hline $\begin{array}{r}\text { Socioeconomic } \\
\text { cluster }\end{array}$ & $\mathbf{2 0 0 0 / 0 1}$ & $\mathbf{2 0 0 4 / 0 5}$ & $\mathbf{2 0 0 9 / 1 0}$ & $\mathbf{2 0 1 0 / 1 1}$ \\
& $\begin{array}{r}\text { \% advancing, } \\
\text { tracked up to } \\
\mathbf{2 0 0 8 / 0 9}\end{array}$ & $\begin{array}{r}\text { \% advancing, } \\
\text { tracked up to } \\
\mathbf{2 0 1 1 / 1 2}\end{array}$ & $\begin{array}{r}\text { \% advancing, } \\
\text { tracked up to } \\
\mathbf{2 0 1 7 / 1 8}\end{array}$ & $\begin{array}{r}\text { \% advancing, } \\
\text { tracked up to } \\
\mathbf{2 0 1 8} / \mathbf{1 9}\end{array}$ \\
\hline Jewish system & & & 33.5 & 33.5 \\
\hline $1-4$ & 29.3 & 32.5 & 48.9 & 48.9 \\
\hline $5-7$ & 45.3 & 50.4 & 64.4 & 64.4 \\
\hline Did not advance & 59.8 & 65.0 & 54.8 & 54.8 \\
\hline
\end{tabular}

Table 7. Percent of First-Degree Recipients in STEM Subjects, Selected Western Countries, 2015

\begin{tabular}{rrrr}
\hline Country & $\begin{array}{r}\text { Science, mathematics, } \\
\text { statistics }\end{array}$ & $\begin{array}{c}\text { ICT and computer } \\
\text { science }\end{array}$ & Engineering \\
\hline Germany & 7 & 7 & 7 \\
\hline UK & 17 & 9 & 14 \\
\hline Austria & 9 & 9 & 8 \\
\hline France & 9 & 11 & 7 \\
\hline Canada & 11 & 10 & 6 \\
\hline U.S. & 10 & 8 & 6 \\
\hline Australia & 8 & 4 &
\end{tabular}

Table 8. Percent of First-Degree STEM Enrollment in Israeli Institutions, Selected Years

\begin{tabular}{rlll} 
& $\mathbf{2 0 0 6 / 0 7}$ & $\mathbf{2 0 1 4 / 1 5}$ & $\mathbf{2 0 1 7 / 1 8}$ \\
\hline Total, N & 163,300 & 191,690 & 189,845 \\
\hline Math, statistics, computer science & $4.7 \%$ & $6.5 \%$ & $8.2 \%$ \\
\hline Physical sciences & $1.8 \%$ & $1.8 \%$ & $1.4 \%$ \\
\hline Biological sciences & $3.2 \%$ & $2.6 \%$ & $2.5 \%$ \\
\hline Engineering and architecture & $17.5 \%$ & $18.0 \%$ & $19.3 \%$ \\
\hline
\end{tabular}

Table 9. Percent of First-Degree Enrollment in STEM Subjects and Education, Selected Cities, 2017 Academic Year

\begin{tabular}{rrrrrrrr}
\hline City & $\begin{array}{r}\text { Socio-economic } \\
\text { index }\end{array}$ & $\begin{array}{r}\text { Ed. and } \\
\text { teacher } \\
\text { training }\end{array}$ & $\begin{array}{r}\text { Math, } \\
\text { statistics, } \\
\text { computer } \\
\text { science }\end{array}$ & $\begin{array}{r}\text { Physical } \\
\text { science }\end{array}$ & $\begin{array}{r}\text { Biological } \\
\text { science }\end{array}$ & $\begin{array}{r}\text { Engineering } \\
\text { and } \\
\text { architecture }\end{array}$ \\
\hline Ramat Hasharon & 9 & 8.2 & 8.2 & 2.1 & 2.1 & 2.1 \\
\hline Givat Shmuel & 8 & 10.5 & 10.5 & 1.8 & 1.8 & 1.8 \\
\hline Givatayim & 8 & 10.5 & 10.5 & 2.4 & 2.4 & 2.4 \\
\hline
\end{tabular}




\begin{tabular}{rrrrrrr}
\multicolumn{3}{c}{ http://irhe.sciedupress.com } & \multicolumn{3}{c}{ Vol. 6, No. 4; 2021 } \\
\hline Modi' 'in-Maccabim-Re'ut & 8 & 11.2 & 11.2 & 2.7 & 2.7 & 2.7 \\
\hline Ra'ananna & 8 & 10.5 & 10.5 & 1.6 & 1.6 & 1.6 \\
\hline Shoham & 8 & 11.3 & 11.3 & 1.7 & 1.7 & 1.7 \\
\hline Tel Aviv-Yafo & 8 & 9.4 & 9.4 & 3.0 & 3.0 & 3.0 \\
\hline Ramat Gan & 7 & 10.5 & 10.5 & 1.8 & 1.8 & 1.8 \\
\hline Haifa & 7 & 14.3 & 14.3 & 1.5 & 1.5 & 1.5 \\
\hline Ashdod & 5 & 12.5 & 12.5 & 1.4 & 1.4 & 1.4 \\
\hline Beersheva & 5 & 15.2 & 15.2 & 1.7 & 1.7 & 1.7 \\
\hline Jerusalem & 4 & 23.8 & 23.8 & 1.6 & 1.6 & 1.6 \\
\hline Lod & 4 & 21.2 & 21.2 & 1.5 & 1.5 & 1.5 \\
\hline Kiryat Malachi & 4 & 31.9 & 31.9 & 0.2 & 0.2 & 0.2 \\
\hline Ramle & 4 & 21.4 & 21.4 & 0.8 & 0.8 & 0.8 \\
\hline Sderot & 4 & 30.6 & 30.6 & 0.5 & 0.5 & 0.5 \\
\hline Tayibbe & 3 & 37.2 & 37.2 & 1.4 & 1.4 & 1.4 \\
\hline Tamra & 3 & 27.4 & 27.4 & 1.4 & 1.4 & 1.4 \\
\hline Netivot & 3 & 39.5 & 39.5 & 1.0 & 1.0 & 1.0 \\
\hline Umm el-Fahem & 2 & 24.8 & 24.8 & 1.2 & 1.2 & 1.2 \\
\hline Bnei Brak & 2 & 22.4 & 22.4 & 0.4 & 0.4 & 0.4
\end{tabular}

Table 10. Higher Education, Selected Cities, by Socioeconomic Index (2017)

\begin{tabular}{rrrrrr} 
City & $\begin{array}{r}\text { Socio-economic } \\
\text { index }\end{array}$ & $\begin{array}{r}\text { Pct. of } \\
\text { students in } \\
\text { city }\end{array}$ & $\begin{array}{r}\text { Pet. attending } \\
\text { universities }\end{array}$ & $\begin{array}{r}\text { Pct. attending } \\
\text { education } \\
\text { colleges }\end{array}$ & $\begin{array}{r}\text { Pct. degree } \\
\text { recipients } \\
\text { (2016) }\end{array}$ \\
\hline Ramat Hasharon & 9 & 10.2 & 51.5 & 4.2 & 4.2 \\
\hline Givatayim & 9 & 9.4 & 45.7 & 6.3 & 6.3 \\
\hline Givat Shmuel & 8 & 11.8 & 72.1 & 6.4 & 6.4 \\
\hline Shoham & 8 & 10.9 & 50.4 & 12.3 & 12.3 \\
\hline Ra'ananna & 8 & 10.7 & 53.5 & 5.9 & 5.9 \\
\hline Modi'in-Maccabim-Re'ut & 8 & 8.4 & 52.5 & 9.2 & 9.2 \\
\hline Tel Aviv-Yafo & 8 & 8.2 & 43.4 & 5.9 & 5.9 \\
\hline Haifa & 7 & 6.0 & 52.8 & 13.8 & 13.8 \\
\hline Beersheva & 5 & 5.6 & 37.6 & 16.3 & 16.3 \\
\hline Ashdod & 5 & 5.2 & 28.0 & 10.5 & 10.5 \\
\hline Lod & 4 & 3.3 & 25.7 & 13.0 & 13.0 \\
\hline Ramle & 4 & 2.9 & 22.6 & 11.3 & 11.3 \\
\hline Jerusalem & 4 & 2.9 & 37.2 & 22.6 & 22.6 \\
\hline Sderot & 4 & & 12.2 & 27.8 & 27.8 \\
\hline Kiryat Malachi & 4 & & 10.5 & 30.4 & 30.4 \\
\hline Tamra & 3 & 4.0 & & 17.5 & 17.5 \\
\hline Tayibbe & 3 & 2.9 & 36.0 & 29.5 & 29.5 \\
\hline Netivot & 3 & & 8.5 & 55.4 & 55.4 \\
\hline Bnei Brak & 2 & 2.3 & & 18.3 & 18.3 \\
\hline & 0.9 & 20.6 & 38.7 & 38.7 \\
\hline
\end{tabular}


Table 11. Dropout Rate, by Type of Institution and Parents' Education, 2016/17 Academic Year

\begin{tabular}{|c|c|c|c|c|c|c|c|}
\hline & \multirow[t]{2}{*}{$\begin{array}{r}\text { Avg., all } \\
\text { institutions }\end{array}$} & \multirow[t]{2}{*}{ Univ. } & \multirow[t]{2}{*}{$\begin{array}{r}\text { Budgeted } \\
\text { colleges }\end{array}$} & \multirow[t]{2}{*}{$\begin{array}{r}\text { Non-budgeted } \\
\text { colleges }\end{array}$} & \multirow[t]{2}{*}{$\begin{array}{l}\text { Educ. } \\
\text { colleges. }\end{array}$} & \multicolumn{2}{|c|}{$\begin{array}{r}\begin{array}{r}\text { Dropout rate by parents' } \\
\text { educ. }\end{array} \\
\text { educt }\end{array}$} \\
\hline & & & & & & $\begin{array}{l}\text { No acad. } \\
\text { educ. }\end{array}$ & $\begin{array}{r}\text { At least 1 } \\
\text { parent with } \\
\text { educ. }\end{array}$ \\
\hline $\begin{array}{r}\text { Dropout } \\
\text { rate }\end{array}$ & $8.7 \%$ & $7.4 \%$ & $8.0 \%$ & $8.8 \%$ & $13.7 \%$ & $9.6 \%$ & $7.3 \%$ \\
\hline
\end{tabular}

Table 12. Average Dropout Rate by Socioeconomic Ranking of Cities

\begin{tabular}{rrrrrrrrrrr}
\hline $\begin{array}{c}\text { Index of } \\
\text { cities }\end{array}$ & $\mathbf{1}$ & $\mathbf{2}$ & $\mathbf{3}$ & $\mathbf{4}$ & $\mathbf{5}$ & $\mathbf{6}$ & $\mathbf{7}$ & $\mathbf{8}$ & $\mathbf{9}$ & $\mathbf{1 0}$ \\
\hline $\begin{array}{r}\text { Drop-out } \\
\text { rate }\end{array}$ & $18.7 \%$ & $10.0 \%$ & $10.2 \%$ & $11.0 \%$ & $8.5 \%$ & $7.7 \%$ & $7.0 \%$ & $6.9 \%$ & $6.9 \%$ & $5.5 \%$ \\
\hline
\end{tabular}

\section{Copyrights}

Copyright for this article is retained by the author(s), with first publication rights granted to the journal.

This is an open-access article distributed under the terms and conditions of the Creative Commons Attribution license (http://creativecommons.org/licenses/by/4.0/). 